Margaret E.I. Kipp, Phd Student

Faculty of Information and Media Studies

University of Western Ontario

mkipp@uwo.ca

\title{
Cycles of Struggle in Biotechnology: \\ Open Source Methods
}




\section{Outline}

1. Introduction

2. Research Questions

3. Open Source Software

4. Open Source Seeds

5. Cycles of Struggle: Open Source

Methods

6. Conclusion 


\section{Introduction}

- Use of open source methodologies in other contexts illustrates increasing interest in grassroots democratic movements participating in the continuing process of balance between public and private interests.

- These efforts provide a possible alternate framework for policy decisions concerning intellectual property. 


\section{Motivation and Focus}

- Motivation:

- Increasing pressure from multinational corporations to strengthen IP laws (via TRIPS)

- Increasing grasp of what is covered under IP laws

- Question: If code can be released under an alternative license, why not seeds?

- Focus:

- Critical Analysis of Open source software and Farmer's rights groups

- Specifically focusing on organisational structure, information exchange, and intellectual property 


\section{Research Questions}

1. How are the methodologies used by farmers' groups similar to those used in open source development and how do they differ?

2. How are groups organised, how are leaders chosen and how do they handle organisation, planning and intergroup communication?

3. How do groups ensure their collective works cannot be commodifed without their consent? 


\section{Open Source Software}




\section{A Brief History of}

\section{Software... \\ and IP}

- 1960s - software distributed relatively openly within the community of programmers (corporate and academic)

- 1980s - software increasingly seen as a product, companies begin to demand IP protection (both copyright and patent)

- Present - many countries provide copyright protection for software, few countries allow software patents... but this is changing 


\section{Copyright vs. Patent (a small digression)}

- Copyright - a monopoly granted on the expression of an idea

- (e.g. source code for an online shopping cart.)

- Patent - a monopoly granted on the idea

- (e.g. idea of an online shopping cart.)

- Some things are not patentable subject matter (e.g. In Canada, software and higher lifeforms)

- The Issue:

- Software patents could halt attempts to compete with or interoperate with a patented product. Genetic patents have a similar effect. 


\section{Stallman and the GPL}

- Richard Stallman's GNU Manifesto:

- write an operating system (GNU) and release it under a different kind of license a copyleft license

- GNU General Public License (GPL):

- You may copy and distribute verbatim copies of the programme as long as you include appropriate attributions (copyright) and do not impose any other restrictions.

- Protects code from inclusion in proprietary programme without permission 


\section{Linus and Linux}

- 1990s - Linus Torvalds, then a computer science student, released an operating system kernel under the GPL

- Linux is freely available and can be run on many different types of computers

- Linux is not the only successful open source project (e.g. Apache, Perl) 


\section{Principles of Open Source}

- Yochai Benkler suggests that open source is a new form of production with:

- Democratic participation

- Loose organisation

- Overall direction decided by participants

- Distributed information exchange facilitated by the Internet

- A better ability to identify the best people for a task

- Result: Commons-based peer production 


\section{Project Management}

- Eric Raymond studied open source project management

- Management tasks:

- defining goals

- monitoring progress

- motivating participants

- organising work

- marshalling resources

- All tasks are part of the cycle of information dissemination and use in any organisation 


\section{Decision Making, Leadership and Motivation...}

- Decision Making: decisions made communally by participants

- Leadership: chosen rather than assigned, leaders feel compelled to give back to the community by taking on a larger role

- Motivation: programmers motivated by creative interest and desire for peer review

- Communication: information exchange decentralised over the Internet 


\section{Open Source Seeds}




\section{A Brief History of Agriculture and Biotechnology}

- Farming began between 7000 and 10000 years ago

- $60 \%$ of population in the developing world farms vs. $3 \%$ in developed countries

- Farmers save seeds for next years crop to save money

- Innovations in farming allow farmers to increase yields beyond subsistence level 


\section{Plant Hybridization and IP}

- Breeding of two similar plants to create hardier plant

- Hybrid plants do not germinate as well

- This places seeds in the marketplace as farmers need to buy new seed every year to ensure good yields, they can no longer save seeds.

- Plant breeder's rights developed to compensate plant breeders for time/money in developing new plants

- Farmers could still breed own varieties and save seeds... 


\section{Genetic Engineering and IP}

- Genetic engineering involves placing genes from one organism into another creating a genetically modified organism (GMO)

- Genetically engineered plants can be bred to resist drought and disease, have higher yields and better withstand pesticides

- Changes to patent laws allow genes to be patented...

- Companies can license GM seeds to farmers and make seed saving illegal 


\section{Cross-pollination and GMOs}

- Licensing of seeds is controversial, but real problem may be contamination by GMOs

- Cross-pollination (the natural exchange of genes between plants) proven to occur between ordinary and GM plants

- It is not possible to stop this natural process

- A farmer could innocently infringe on a patent or be unable to stop such infringement! 


\section{Monsanto vs. Schmeiser}

- Groups:

- Monsanto - large agricultural research company, licenses its patented GM seeds to farmers

- Schmeiser - Saskatchewan canola farmer, developed his own seed variety and saved his seeds

- Monsanto sued Schmeiser for stealing its genetic material; Schmeiser claimed his plants were contaminated by seeds blown into his field

- Patent law does not allow for innocent infringement 


\section{Monsanto vs. Schmeiser... the verdict}

- SCC ruling - 21 May 2004

- Schmeiser guilty of using Monsanto's genetic material but did not benefit from use

- Dissenting judges felt SCC was de facto granting Monsanto a patent on the canola plants, which is not allowed under Canadian law (see Harvard Mouse)

- SCC did not deal with the issue of innocent infringement! 


\section{Farmers' Rights Movements}

- Like open source development, farmers' rights groups co-ordinate via the Internet, are decentralised and have loose hierarchies

- e.g. MASIPAG - a large network of farmers, scientists and NGOs in the Philippines

- Involved in protesting genetic patents

- Involved in agricultural research 


\section{MASIPAG list of rights vs Stallman's GNU Manifesto}

- MASIPAG rights: - GNU Manifesto:

- Use, save, exchange, multiply, sell genetic

- Everyone will be resources

- Prevent control of seeds or knowledge by multinational corporations permitted to modify and redistribute GNU, but no distributor will be allowed to restrict its further redistribution

Both statements are concerned with facilitating information exchange! 


\section{Decision Making, Leadership and}

Motivation... a comparison

- Decision Making: based on community consensus

- Leadership: leaders tend to self-select due to events in their lives (e.g. Stallman and GNU, Schmeiser and his court battles with Monsanto)

- Motivation: creative urge versus survival

- Project choices: software versus protests and agricultural research

- Shared Methodology: commons-based peer production 


\section{Cycles of Struggle: Open Source Methods}




\section{The Rise of Grassroots Organisations}

- Unions are examples of early grassroots organisations and some attempt to globalise was made

- New movements tend to be global, using the Internet as a low cost facilitator of communications ties; technology is an enabler

- Use open source methods such as free information sharing to participants and observers alike 


\section{Distributed Decision Making}

- Nick Dyer-Witheford suggests open source methodologies are not only a new form of production but show promise of a potential new way of making decisions

- e.g. Highly decentralised forms of planning via the Internet in open source software

- Information dissemination via the Internet with public archives so decisions and debates are public

- Result: A form of distributed town hall democracy 


\section{IP in distribution}

- The GPL protects open source products from being enclosed in a proprietary product, could the same methods work for seeds?

- Some farmers breed their own seeds. Plant breeder's rights or patents could be linked with a license like the GPL to provide the degree of IP protection desired 


\section{Conclusions}

1. Connects two seemingly disparate movements and shows they have many commonalities in goals and methodologies

2.Suggests an alternative method of ensuring the development of goods with a low cost of distribution

3. Suggests an alernative method of information sharing/decision making allowing greater democratic participation in intellectual property policy formulation 


\section{Margaret E.I. Kipp, Phd Student}

Faculty of Information and Media Studies

\section{University of Western Ontario} mkipp@uwo.ca

\section{Thank you}

